\title{
Analisis Hubungan Norma Subjektif Terhadap Minat Pengusaha UMKM Untuk Membuat Laporan Keuangan Berbasis SAK ETAP Dengan Kemampuan Akuntansi Sebagai Variabel Moderasi
}

\author{
Rizki Fitri Amalia \\ Politeknik PalComTech \\ rizki_fitri@palcomtech.ac.id \\ Nurussama \\ Politeknik PalComTech \\ nurussama@palcomtech.ac.id
}

\begin{abstract}
Abstrak Penelitian ini bertujuan untuk mengetahui lebih lanjut mengenai analisis hubungan norma subjektif terhadap minat pengusaha UMKM untuk membuat laporan keuangan berbasis SAK ETAP. Penelitian ini menggunakan analisis regresi moderasi. Objek penelitian ini adalah semua UMKM di Kota Palembang. Hasil penelitian ini menyatakan bahwa kemampuan akuntansi belum mampu untuk memoderasi hubungan antara norma subjektif dengan minat untuk membuat laporan keuangan berbasis SAK ETAP. Hal ini menunjukkan bahwa kemampuan akuntansi bukanlah faktor pendukung yang dapat memperkuat ataupun memperlemah minat untuk membuat pelaporan keuangan. Dengan kata lain pengusaha UMKM yang ada di Kota Palembang memiliki pertimbangan pendukung lain dalam membetuk minatnya untuk membuat laporan keuangan berbasis SAK ETAP.
\end{abstract}

Kata Kunci Norma Subjektif, Minat, Kemampuan Akuntansi, SAK ETAP dan UMKM Kota Palembang

\section{PENDAHULUAN}

Dewasa ini, para pelaku usaha yang ada di Indonesia dituntut untuk dapat menyelenggarakan pelaporan keuangan baik secara sederhana maupun komprehensif. Pelaporan keuangan ini merupakan bentuk "pertanggungjawaban" atas pelaksanaan usaha yang dilakukan dan sebagai informasi dalam memperhitungkan pajak yang tertanggung pada usaha tersebut. Hal ini sejalan dengan Kitab UndangUndang Hukum Dagang (KUHD) pasal 6 yang berbunyi: "tiap-tiap orang yang melakukan/menjalankan usaha wajib untuk menyelenggarakan pembukuan usaha, sehingga diketahui segala hak dan kewajibannya". Para pelaku UMKM menganggap pembukuan adalah sesuatu yang rumit untuk dilaksanakan dan tidak merasa perlu untuk melakukan pencatatan. Bagi sebagian pelaku UMKM pencatatan keuangan tidak diperlukan karena ukuran usahanya yang masih kecil. Padahal pencatatan dan pelaporan keuangan dapat membantu pemilik mengetahui posisi keuangan dan kinerja perusahaan dengan akurat dan relevan (Soraya dan Mahmud, 2016).

Selain sebagai bentuk pertanggung-jawaban, laporan keuangan juga berfungsi sebagai penyedia informasi-informasi yang berguna untuk pengambilan keputusan baik untuk pihak internal maupun pihak eksternal. Bagi pihak internal laporan keuangan digunakan untuk melihat "kesehatan" aspek keuangan yang ada didalam sebuah usaha. Contohnya seperti laporan laba rugi, didalam laporan ini pelaku usaha bisa menganalisis tingkat efisiensi aktivitas dengan melihat besaran harga pokok penjualan dan bebanbeban yang dihasilkan usaha tersebut selama periode tertentu. Bagi pihak eksternal, laporan keuangan menjadi dasar mereka dalam mengambil keputusan apakah akan berinvestasi atau bahkan meminjamkan sejumlah dana kepada pelaku usaha tersebut. Contohnya, pihak kreditor seperti bank ataupun lembaga 
keuangan lainnya selalu mensyaratkan laporan keuangan sebagai syarat utama apabila seorang individu yang menjalankan usaha atau badan usaha ingin melakukan pinjaman dana untuk aktivitas usahanya. Hal ini menunjukkan betapa pentingnya peranan laporan keuangan bagi pelaku usaha.

Namun kesadaran para pelaku usaha khususnya di sektor Usaha Mikro Kecil dan Menengah (UMKM) terkait pentingnya laporan keuangan masi sangat minim. Pelaku Usaha Mikro Kecil Menengah (UMKM) seringkali terkendala bahkan sulit mendapatkan akses perkreditan. Selain karena dinilai tidak penting, pelaku UMKM juga buta terhadap laporan keuangan berbasis SAK ETAP. Banyak diantara mereka yang laporan keuangannya bercampur dengan keuangan pribadi, bahkan ada yang tidak memiliki laporan keuangan sama sekali. Padal SAK ETAP ini ke depannya tentu sangat diharapkan UMKM mampu melakukan pembukuan akuntansi untuk menyajikan laporan keuangan berbasis SAK ETAP yang lebih informatif dengan tujuan tentunya memberikan kemudahan bagi investor maupun kreditor untuk memberikan bantuan pembiayaan bagi para pengusaha UMKM (Andriani, dkk, 2014).

Standar Akuntansi Keuangan (SAK) dirasakan sangat memberatkan bagi Usaha Kecil dan Menengah dibandingkan dengan usaha besar. Salah satu faktor sebagai penyebab hal ini adalah adanya kewajiban UKM yang sama dengan usaha besar yaitu diwajibkannya UKM membuat laporan keuangan sesuai dengan standar akuntansi keuangan internasional. Dengan diterbitkannya Standar Akuntansi Keuangan Entitas Tanpa Akuntabilitas Publik (SAK ETAP) pada tahun 2009 diharapkan mampu memberikan kemudahan bagi UKM dalam membuat laporan keuangan. Namun, realitas yang terjadi adalah SAK ETAP masih dirasa memberatkan, sehingga banyak pengusaha UKM yang masih enggan untuk membuat laporan keuangan bahkan untuk melakukan pencatatan akuntansi (Sariningtyas dan Diah 2011).

Hal ini sejalan dengan adanya berita yang menyatakan "Dari 100 UMKM yang telah mendaftar di pasarsuroboyo, hanya $10 \%$ yang sudah teratur. Sisanya $90 \%$ banyak yang bercampur antara laporan keuangan atau pengeluaran usaha dengan pribadi, bahkan ada yang tidak ada laporan keuangannya sama sekali dan kondisi ini adalah cermin UMKM yang ada sekarang." (kabarbisnis, 2017). Di Palembang sendiri, berdasarkan hasil observasi awal kami didapati bahwa sebagian besar UMKM utamanya usaha mikro dan kecil masi sangat jarang yang membuat pelaporan keuangan. Padahal laporan keuangan sangat berguna dalam menjaga keberlangsungan hidup usaha utamanya atas aspek pengembangan usaha. UMKM yang memiliki modal finansial yang cenderung sangat minim, akan kesulitan untuk melakukan pengembangan usaha apabila tidak ada suntikan dana. Salah satu sumber dana yang bisa dimanfaatkan adalah dana dari pihak ketiga (kreditor), dimana syarat utama untuk mendapatkannya adalah paling tidak menyelenggarakan pelaporan keuangan dari yang sederhana sampai komprehensif sekalipun.

Alasan utama kenapa para pelaku usaha ini enggan untuk menyelenggarakan pelaporan keuangan adalah melihat rekan sesama pengusaha yang juga tidak membuat pelaporan keuangan. Berdasarkan theory of Planned Behavior fenonema ini terjadi karena kurangnya peranan lingkungan sekitar yang dicerminkan oleh variabel norma subjektif. Norma subjektif merupakan dorongan motivasional baik secara langsung ataupun tidak langsung dari seseorang ataupun sekelompok orang kepada seorang individu. Dalam kasus ini, fenomena yang ditemukan adalah tidak adanya dorongan positif dari norma subjektif terhadap minat pelaku usaha khususnya mikro dan kecil untuk membuat pelaporan keuangan.

Mayoritas UMKM di Kota Palembang belum memahami pencatatan akuntansi. Pengusaha UMKM memandang bahwa proses pencatatan akuntansi tidak terlalu penting untuk diterapkan. Hal tersebut menjadi masalah karena akan berpengaruh terhadap keberhasilan pengelolaan usahanya agar dapat berkembang serta menyulitkan dalam mengontrol mengenai informasi akuntansi. Hal inilah yang merupakan permasalahan yang dialami oleh UKM saat ini, sehingga menjadi kendala dalam perkembangan UKM di Kota Palembang. Rendahnya kemauan pengusaha UKM dalam membuat pencatatan akuntansi disebabkan karena pengusaha kecil belum memiliki pengetahuan akuntansi yang memadai, dan banyak diantara mereka yang belum memahami pentingnya pencatatan dan pembukuan bagi kelangsungan usahanya (Andhika dan Damayanti, 2017)

Kemampuan akuntansi merupakan pengaplikasian pemahaman akuntansi dalam praktik sesungguhnya. Seringkali kemampuan akuntansi yang rendah menyebabkan seseorang menjadi "lebih" enggan dalam membuat laporan keuangan dan sebaliknya. Artinya kemampuan akuntansi lebih menjadi faktor pendukung, bukanlah faktor utama. Hal ini dengan asumsi bahwa kebanyakan pelaku usaha seringkali menggunakan jasa pihak ketiga atau merekrut karyawan yang menguasai ilmu kajian akuntansi dibandingkan membuatnya sendiri. Kemampuan akuntansi dalam penelitian ini diidentifikasi sebagai variabel pemoderasi. Menilik fenomena dan argumentasi logis yang telah diungkapkan pada bagian ini, maka peneliti tertarik untuk meneliti dengan judul analisis hubungan norma subjektif terhadap minat 
untuk membuat laporan keuangan berbasis SAK ETAP dengan kemampuan akuntansi sebagai variabel moderasi.

\section{Rumusan Masalah}

Rumusan masalah yang diidentifikasi dari penelitian ini adalah apakah kemampuan akuntansi mampu memoderasi hubungan antara norma subjektif dengan minat untuk membuat laporan keuangan?

\section{Tujuan Penelitian}

Tujuan utama penelitian ini dilakukan adalah untuk melihat bagaimana kemampuan akuntansi mampu memoderasi hubungan antara norma subjektif dengan minat untuk membuat laporan keuangan, khususnya di usaha kecil.

\section{TINJAUAN PUSTAKA}

\section{Theory of Planned Behavior (TPB)}

Theory of Planned Behavior (TPB) merupakan perluasan dari Theory of Reasoned Action (TRA) (Ajzen, 2005). TRA dijelaskan bahwa niat seseorang terhadap perilaku dibentuk oleh dua faktor utama yaitu attitude toward the behavior dan subjective norms (Fishbein dan Ajzen, 1975), sedangkan dalam TPB ditambahkan satu faktor lagi yaitu perceived behavioral control (Ajzen, 1991). TPB sangat sesuai digunakan untuk menjelaskan berbagai perilaku di dalam kewirausahaan. Sebagaimana dikatakan oleh Ajzen (1991), bahwa TPB merupakan model yang tepat untuk menjelaskan konstruk-konstruk yang membentuk perilaku. TPB sendiri terdiri dari konstruk sebagai berikut:

\section{Attitude (Sikap)}

Sikap merupakan suatu faktor dalam diri seseorang yang dipelajari untuk memberikan respon positif atau negatif pada penilaian terhadap sesuatu yang diberikan. Sikap terhadap perilaku merupakan hasil evaluasi kepercayaan-kepercayaan yang ada didalam diri seseorang individu. Sikap merupakan kecenderungan yang dipelajari untuk memberikan respon kepada obyek atau kelas obyek secara konsisten baik dalam rasa suka maupun tidak suka. Sebagai contoh apabila seseorang menganggap sesuatu bermanfaat bagi dirinya maka dia akan memberikan respon positif terhadapnya, sebaliknya jika sesuatu tersebut tidak bermanfaat maka dia akan memberikan respon negatif.

\section{Subjective Norm (Norma Subjektif)}

Subjective norm (norma subjektif) merupakan persepsi seseorang tentang pemikiran orang lain yang akan mendukung atau tidak mendukungnya dalam melakukan sesuatu. Norma subjektif mengacu pada tekanan sosial yang dihadapi oleh individu untuk melakukan atau tidak melakukan sesuatu. Norma subjektif merujuk pada pengaruh dari lingkungan sekitar yang menyebabkan seseorang untuk mau atau tidak mau untuk berperilaku. Hal ini terkait dengan keyakinan bahwa orang lain mendorong atau menghambat untuk melaksanakan perilaku. Seorang individu akan cenderung melakukan perilaku jika termotivasi oleh orang lain yang menyetujuinya untuk melakukan perilaku tersebut.

\section{Perceived Behavioral Control (Kontrol Perilaku)}

Kontrol perilaku adalah persepsi kemudahan atau kesulitan dalam melakukan suatu perilaku. Kontrol perilaku berhubungan dengan kepercayaan akan faktor yang mendkung atau tidak mendukung sebuah perilaku untuk dapat direalisasikan.

\section{Pengaruh Kemampuan Akuntansi terhadap Minat Membuat Laporan Keuangan Berbasis SAK ETAP}

Pengetahuan akuntansi adalah pengetahuan dalam bidang pencatatan akuntansi yang dimiliki oleh seseorang. Rendahnya kemampuan akuntansi dapat menyebabkan menyebabkan banyak perusahaan kecil yang mengalami kegagalan. Rendahnya kemampuan akuntansi merupakan salah satu penyebab rendahnya minat pengusaha UMKM untuk membuat pelaporan keuangan berbasis SAK ETAP. Kemampuan akuntansi sangat dibutuhkan dalam mencapai suatu kinerja yang profesional, sehingga peranan akuntansi berpengaruh dalam pengambilan keputusan. Proses belajar mengenai akuntansi akan meningkatkan pengetahuan akuntansi pengusaha, sehingga pemahaman pengusaha UMKM untuk menerapkan informasi akuntansi dalam membuat laporan keuangan berbasis SAK ETAP juga akan semakin meningkat 


\section{Pengembangan Hipotesis}

Hipotesis yang diusulkan dalam penelitian ini yaitu:

H1: kemampuan akuntansi mampu memoderasi hubungan antara norma subjektif dengan minat menyelenggarakan pelaporan keuangan

\section{Kerangka Pemikiran}

Kerangka pemikiran dalam penelitian ini adalah:

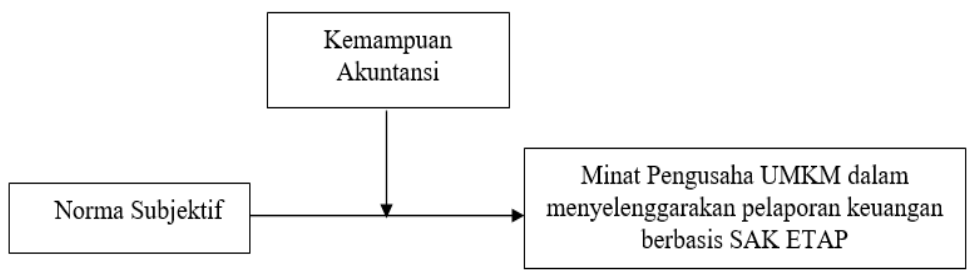

Gambar 2.1

Kerangka Pemikiran

\section{METODE PENELITIAN}

Populasi dan Sampel

Penyebaran kuisioner dilakukan semenjak tanggal 23 April sampai dengan 18 Mei 2018 secara bertahap ke beberapa kecamatan di Kota Palembang yang menjadi sentra UMKM seperti kecamatan Seberang Ulu I, Ilir Timur I, Ilir Timur II, Ilir Barat I, dan Tangga Buntung. Adapun sebanyak 70 kuisioner berhasil disebar dimana 54 kuisioner diisi secara langsung oleh responden sementara 16 kuisioner lainnya ditinggalkan dan diambil kembali 2-3 hari setelahnya.

\section{Teknik Pengambilan Sampel}

Teknik Pengambilan Sampel Yang Digunakan Adalah Purposive Sampling Yaitu Pemilihan Elemen Untuk Menjadi Sampel Berdasarkan Pertimbangan Tertentu.

\section{Metode Analisis Data}

Analisis data pada penelitian ini akan menggunakan teknik analisis regresi moderasi dengan bantuan software SPSS

1. Uji Kualitas Data

a. Uji Validitas

Uji Validitas berhubungan dengan ketepatan alat ukur untuk melakukan tugasnya mencapai sasarannya. Uji validitas ditujukan untuk mengukur seberapa nyata suatu pengujian/instrument mengukur apa yang seharusnya diukur. Pengukuran dinyatakan valid jika mengukur tujuannya dengan nyata atau benar. Pengujian validitas data dalam penelitian ini dilakukan secara statistik yaitu dengan menghitung korelasi antara masing-masing pertanyaan dengan skor total dengan menggunakan metode corrected item - Total Correlation.

b. Uji Reliabilitas

Uji Reliabilitas data untuk mengetahui seberapa besar pengukur mengukur dengan stabil dan konsisten (Ghozali, 2011:28). Jadi reliabilitas menunjukkan apakah instrumen tersebut secara konsisten memberikan hasil ukuran yang sama tentang sesuatu yang diukur pada waktu yang berlainan. Besarnya tingkat reliabilitas ditunjukkan oleh nilai koefisiennya, yaitu koefisien reliabilitas. Pengujian reliabilitas dilakukan dengan menggunakan cronbach alpha. Koefisien cronbach alpha yang lebih dari 0,60 menunjukkan keandalan (reliabilitas) instrumen. Selain itu, cronbach alpha yang semakin mendekati 1 menunjukkan konsistensi reliabilitas internalnya.

2. Analisis Regresi Moderasi (MRA)

Pengujian dengan menggunakan model regresi linier dengan bantuan program SPSS. Regresi linier di gunakan untuk mendeteksi beberapa variabel yang berelasi dengan variabel yang diuji. Uji regresi mengetahui arah dan besarnya pengaruh antara variabel independen dengan variabel dependennya. Model dalam pengujian ini dapat dirumuskan sebagai berikut: 
$\mathrm{MN}=\alpha+\beta \mathrm{NS}+\beta \mathrm{KA}+\beta \mathrm{NS}^{*} \mathrm{KA}+\varepsilon$

Dimana:

$\alpha=$ Koefisien

$\beta=$ Beta

$\mathrm{MN}=$ Minat Untuk Membuat Laporan Keuangan

NS $=$ Norma Subjektif

$\mathrm{KA}=$ Kemampuan Akuntansi

$\varepsilon=$ Standar error

\section{PEMBAHASAN}

\section{Hasil Pengumpulan Data}

Penyebaran kuisioner dilakukan selama kurang lebih 14 hari, dimana peneliti mendatangi secara langsung usaha-usaha kecil yang ada di Kota Palembang. Sebelum melakukan pembagian kuisioner, peneliti menanyakan kesediaan responden untuk mengisi kuisioner dan memberikan penjelasan singkat terkait teknis pengisian kuisioner ini. Adapun rincian hasilnya ditunjukkan pada tabel berikut:

Tabel 1. Total pengumpulan kuesioner

\begin{tabular}{|l|l|l|}
\hline No & Keterangan & Jumlah \\
\hline 1 & Jumlah kuisioner yang dibagikan & 62 \\
\hline 2 & Jumlah kuisioner yang tidak dikembalikan/ditolak & $(3)$ \\
\hline 3 & $\begin{array}{l}\text { Jumlah kuisioner yang tidak memenuhi karakteristik } \\
\text { sampel dalam penelitian ini }\end{array}$ & $(8)$ \\
\hline 4 & Total Kuisioner & $\mathbf{5 1}$ \\
\hline
\end{tabular}

\section{Uji Kualitas Data}

\section{Uji Validitas}

Uji validitas data dalam penelitian ini dengan menggunakan analisis bivariate yang ada di SPSS 23. Hasil uji validitas norma subjektif ditunjukkan pada tabel berikut ini:

Tabel 2. Hasil Uji Validitas Norma Subjectives

\begin{tabular}{|c|c|c|c|c|}
\hline Variabel & Butir & r-hitung & r-tabel & Keterangan \\
\hline \multirow{4}{*}{ Norma Subjektif } & 1 & 0,756 & 0,271 & Valid \\
\cline { 2 - 5 } & 2 & 0,874 & 0,271 & Valid \\
\cline { 2 - 5 } & 3 & 0,865 & 0,271 & Valid \\
\cline { 2 - 5 } & 4 & 0,746 & 0,271 & Valid \\
\cline { 2 - 5 } & 5 & 0,873 & 0,271 & Valid \\
\hline
\end{tabular}

Dari hasil diatas dapat disimpulkan bahwa seluruh butir pertanyaan dalam penelitian ini valid. Hal ini dikarenakan tingkat signifikansi seluruh butir pertanyaan variabel norma subjektif lebih kecil dari 0,05 . Selain itu, apabila kita membandingkan $\mathrm{r}$ hitung dan $\mathrm{r}$ tabel maka hasilnya seluruh $\mathrm{r}$ hitung butir pertanyaan variabel norma subjektif lebih besar dari $r$ tabel 0,271 . Pengujian berikutnya akan dilakukan untuk validitas variabel kemampuan akuntansi dengan hasil sebagai berikut:

Tabel 3. Hasil Uji Validitas Kemampuan Akuntansi

\begin{tabular}{|c|c|c|c|c|}
\hline Variabel & Butir & r-hitung & r-tabel & Keterangan \\
\hline \multirow{4}{*}{ Norma Subjektif } & 1 & 0,841 & 0,271 & Valid \\
\cline { 2 - 5 } & 2 & 0,792 & 0,271 & Valid \\
\cline { 2 - 5 } & 3 & 0,912 & 0,271 & Valid \\
\cline { 2 - 5 } & 4 & 0,836 & 0,271 & Valid \\
\cline { 2 - 5 } & 5 & 0,867 & 0,271 & Valid \\
\cline { 2 - 5 } & 6 & 0,892 & 0,271 & Valid \\
\hline
\end{tabular}


Berdasarkan hasil uji validitas diatas, dapat disimpulkan bahwa seluruh butir pertanyaan dalam penelitian ini valid. Hal ini dikarenakan tingkat signifikansi seluruh butir pertanyaan variabel kemampuan akuntansi lebih kecil dari 0,05. Selain itu, apabila kita membandingkan $r$ hitung dan $r$ tabel maka hasilnya seluruh $r$ hitung butir pertanyaan variabel norma subjektif lebih besar dari $r$ tabel 0,271 . Pengujian berikutnya akan dilakukan untuk validitas variabel minat untuk membuat laporan keuangan dengan hasil sebagai berikut:

Tabel 4. Hasil Uji Validitas Minat

\begin{tabular}{|c|c|c|c|c|}
\hline Variabel & Butir & r-hitung & r-tabel & Keterangan \\
\hline \multirow{4}{*}{ Minat } & 1 & 0,855 & 0,271 & Valid \\
\cline { 2 - 5 } & 2 & 0,917 & 0,271 & Valid \\
\cline { 2 - 5 } & 3 & 0,845 & 0,271 & Valid \\
\cline { 2 - 5 } & 4 & 0,893 & 0,271 & Valid \\
\hline
\end{tabular}

Berdasarkan hasil uji validitas diatas, dapat disimpulkan bahwa seluruh butir pertanyaan dalam penelitian ini valid. Hal ini dikarenakan tingkat signifikansi seluruh butir pertanyaan variabel minat membuat laporan keuangan lebih kecil dari 0,05 . Selain itu, apabila kita membandingkan $r$ hitung dan $r$ tabel maka hasilnya seluruh $r$ hitung butir pertanyaan variabel norma subjektif lebih besar dari $r$ tabel 0,271. Kesimpulannya, seluruh butir pertanyaan dalam penelitian ini memenuhi aspek validitas. Maka langkah selanjutnya ada melakukan pengujian reliabilitas.

\section{Uji Reliabilitas}

Uji reliabilitas dilakukan dengan melihat nilai croncobach alpha, apabila nilai croncobach alpha lebih besar dari 0,60 maka sebuah pertanyaan dapat dikatan reliabel atau dapat dihandalkan. Berikut hasil uji reliabilitas pada penelitian ini:

Tabel 5. Uji Reliabilitas

\begin{tabular}{|l|l|l|}
\hline No & Variabel & Croncobach Alpha \\
\hline 1 & Norma Subjektif & 0,881 \\
\hline 2 & Kemampuan Akuntansi & 0,932 \\
\hline 3 & Minat Membuat Laporan Keuangan & 0,896 \\
\hline \multicolumn{2}{|l}{ Sumber: data diolah peneliti }
\end{tabular}

Berdasarkan pada hasil pengujian diatas, didapatkan bahwa nilai croncobach alpha variabel norma subjektif sebesar 0,881, kemampuan akuntansi 0,932 , dan minat membuat laporan keuangan sebesar 0,896 yang kesemuanya lebih besari 0,60 , sehingga seluruh pertanyaan dalam penelitian ini terbukti reliabel.

\section{Uji Asumsi Klasik \\ Uji Normalitas}

Uji normalitas diperuntukkan untuk melihat bagaimana arah distribusi data dalam sebuah penelitian dinyatakan sudah terdistribusi normal apabila arah data sejalan dengan garis diagonal yang ada dalam grafik atau nilai signifikansinya lebih besar dari 0,05 dengan standar keyakinan 95\%. Adapun hasil normalitas dalam penelitian ini adalah: 
Tabel 6. Uji Normalitas

\begin{tabular}{|c|c|c|}
\hline \multicolumn{3}{|c|}{ One-Sample Kolmogorov-Smirnov Test } \\
\hline & & $\begin{array}{c}\text { Unstandardized } \\
\text { Residual } \\
\end{array}$ \\
\hline \multicolumn{2}{|l|}{$\mathrm{N}$} & 51 \\
\hline \multirow[t]{2}{*}{ Normal Parametersa.b } & Mean & 0000000 \\
\hline & Std. Deviation & 1,77912945 \\
\hline \multirow[t]{3}{*}{ Most Extreme Differences } & Absolute & 104 \\
\hline & Positive & 071 \\
\hline & Negative & -104 \\
\hline \multicolumn{2}{|l|}{ Test Statistic } & 104 \\
\hline \multicolumn{2}{|l|}{ Asymp. Sig. (2-tailed) } & $200^{\mathrm{c}, \mathrm{d}}$ \\
\hline \multicolumn{3}{|l|}{ a. Test distribution is Normal. } \\
\hline \multicolumn{3}{|l|}{ b. Calculated from data. } \\
\hline \multicolumn{3}{|c|}{ c. Lilliefors Significance Correction. } \\
\hline \multicolumn{3}{|c|}{ d. This is a lower bound of the true significance. } \\
\hline
\end{tabular}

Berdasarkan pada hasil pengujian diatas, nilai signifikansinya sebesar 0,200 atau lebih besar dari 0,05. Hal ini berarti bahwa data dalam penelitian ini normal dan dapat digunakan.

\section{Uji Multikolinieritas}

Uji multikolinieritas dalam penelitian ini dilakukan dengan melihat nilai VIF dan Tolerance dari masingmasing variabel independen. Variabel yang terbebas dari gejala multikolinieritas apabila nilai VIF lebih besar dari 0,1 dan kurang dari 1, dan nilai tolerance kurang dari 10 (Ghozali, 2016). Berikut ini disajikan hasil pengujian multikolinieritas pada model penelitian ini:

Tabel 7. Uji Multikolineritas

\begin{tabular}{|c|c|c|c|c|c|c|c|c|}
\hline \multicolumn{9}{|c|}{ Coefficients $^{\mathrm{a}}$} \\
\hline \multirow{2}{*}{\multicolumn{2}{|c|}{ Model }} & \multicolumn{2}{|c|}{$\begin{array}{l}\text { Unstandardized } \\
\text { Coefficients }\end{array}$} & \multirow{2}{*}{\begin{tabular}{|c|}
$\begin{array}{c}\text { Standardized } \\
\text { Coefficients }\end{array}$ \\
Beta \\
\end{tabular}} & \multirow[b]{2}{*}{$t$} & \multirow[b]{2}{*}{ Sig. } & \multicolumn{2}{|c|}{ Collinearity Statistics } \\
\hline & & B & Std. Error & & & & Tolerance & VIF \\
\hline 1 & (Constant) & 8,212 & 5,158 & & 1,592 & .118 & & \\
\hline & NS TOTAL & 349 & 270 & 442 & 1,292 & 203 & 086 & 11,691 \\
\hline & $\begin{array}{l}\text { KEM_TOT } \\
\text { AL }\end{array}$ &,- 414 &, 499 &,- 470 &,- 830 &, 411 &, 031 & 31,969 \\
\hline & NS KEM &, 022 &, 026 & .578 &, 858 & 395 &, 022 & 45,388 \\
\hline
\end{tabular}

a. Dependent Variable: MN TOTAL

Hasil pengujian multikolinieritas diatas terlihat bahwasannya nilai tolerance masi berkisar di rentang 0,1 sampai dengan dibawah 1 yang artinya tidak terindikasi gejala multikolinieritas. Hal ini berbanding terbalik dengan nilai VIF dari seluruh variabel yang diujikan ternyata melebihi angka 10, bahkan mencapai 45,388 yang artinya terkena multikolinieritas. Namun, dalam penelitian yang menggunakan model moderasi akan wajar jika terkena multikolinieritas dikarekanan variabel independen dan pemoderasi saling berinteraksi (Jogiyanto, 2007). Berdasarkan hal tersebut maka gejala multikolinieritas dapat diabaikan.

\section{Uji Heterokedastisitas}

Uji heterokedastisitas dalam penelitian ini menggunakan uji glejser. Uji glejser dilakukan dengan cara meregresikan nilai absolut residual terhadap variabel independen (Gujarati, 2003 dalam Imam Ghozali, 2016). Adapun hasil pengujian heterokedastisitas dalam penelitian ini ditunjukkan pada tabel berikut ini: 
Tabel 8. Uji Heterokedastisitas

\begin{tabular}{|c|c|c|c|c|c|}
\hline & \multicolumn{5}{|c|}{ Coefficients ${ }^{a}$} \\
\hline \multirow[b]{2}{*}{ Model } & \multicolumn{2}{|c|}{ Unstandardized Coefficients } & $\begin{array}{l}\text { Standardized } \\
\text { Coefficients }\end{array}$ & & \\
\hline & B & Std. Error & Beta & $\mathrm{t}$ & Sig. \\
\hline (Constant) & 7,858 & 3,326 & & 2,362 &, 022 \\
\hline NS TOTAL & -332 & .174 & -913 & $-1,906$ & 063 \\
\hline KEM_TOTAL & -582 & 322 & $-1,433$ & $-1,811$ & 077 \\
\hline NS KEM &, 029 & 017 & 1,649 & 1,748 & 087 \\
\hline
\end{tabular}

a. Dependent Variable: ABS RES

Berdasarkan hasil tabel di atas maka dapat dilihat bahwa nilai signifikansi variabel norma subjektif 0,063 dan kemampuan akuntansi 0,077 lebih besar dari 0,05. Artinya model dalam penelitian ini terbebas dari masalah heterokedastisitas dan dapat dilanjutkan untuk pegujian hipotesis.

\section{Uji Regresi Moderasi}

Regresi moderasi dilakukan dengan menggunakan bantuan program SPSS 23, adapun model dalam penelitian ini diestimasi sebagai berikut:

$\mathrm{MN}=\alpha+\beta \mathrm{NS}+\beta \mathrm{KA}+\beta \mathrm{NS} * \mathrm{KEM}+\varepsilon$

Dimana:

$\alpha=$ Koefisien

$\beta=$ Beta

$\mathrm{MN}=$ Minat Untuk Membuat Laporan Keuangan

NS = Norma Subjektif

$\mathrm{KEM}=$ Kemampuan Akuntansi

$\varepsilon=$ Standar error

Berdasarkan hasil pengujian regresi berganda maka didapatkan hasil sebagai berikut:

Tabel 9. Uji Regresi Moderasi

\begin{tabular}{|c|c|c|c|c|c|c|}
\hline \multicolumn{7}{|c|}{ Coefficients $^{\mathrm{a}}$} \\
\hline \multirow{2}{*}{\multicolumn{2}{|c|}{ Model }} & \multirow{2}{*}{\multicolumn{2}{|c|}{ Unstandardized Coefficients }} & & & \\
\hline & & & & $\begin{array}{c}\text { Coefficients } \\
\text { Beta }\end{array}$ & t & Siq \\
\hline \multirow[t]{4}{*}{1} & (Constant) & 8,212 & 5,158 & & 1,592 & .118 \\
\hline & NS TOTAL & 349 & 270 & 442 & 1,292 & 203 \\
\hline & KEM_TOTAL & -414 & 499 & -470 & -830 & 411 \\
\hline & NS KEM & .022 & .026 & 578 & .858 & 395 \\
\hline
\end{tabular}

a. Dependent Variable: MN TOTAL

Berdasarkan pada tabel tersebut maka estimasi model regresi linear berganda pada penelitian ini adalah "MN $=8,212+0,349 \mathrm{NS}+-0,414 \mathrm{KEM}+0,022 \mathrm{NS}$ KEM $\varepsilon "$.

\section{Uji Koefisien Determinasi}

Uji koefisien determinasi dilakukan dengan melihat adjusted $R$ Square. Adapun nilai koefisien determinasi pada model penelitian ini adalah sebagai berikut:

Tabel 10. Uji Koefisien Determinasi 


\begin{tabular}{|c|c|}
\hline Model & Adjusted R Square \\
\hline 1 & 0,500 \\
\hline
\end{tabular}

Berdasarkan pada tabel diatas maka dapat dilihat nilai adjusted R Square penelitian ini sebesar 0,500. Artinya, variabel independen dalam penelitian ini mampu menjelaskan hubungannya dengan variabel dependen sebesar $50 \%$. Sementara sisanya sebesar dipengaruhi oleh variabel lainnya diluar model penelitian ini.

\section{Uji F}

Pada dasarnya uji $\mathrm{F}$ digunakan untuk melihat kemampuan suatu model untuk menjelaskan sebuah permasalahan atau sering disebut kelayakan suatu model, adapun hasil uji $\mathrm{F}$ dalam penelitian ini:

Tabel 11. Uji F

\begin{tabular}{|c|c|c|}
\hline Model & F & Sig \\
\hline Regression & 17,656 & 0,000 \\
\hline
\end{tabular}

Berdasarkan pada hasil tabel diatas dapat diketahui bahwa nilai signifikansi uji F sebesar 0,000 atau lebih kecil dari 0,05 . Artinya model dalam penelitian ini baik untuk digunakan.

\section{Uji Regresi Moderasi}

Uji regresi moderasi dalam penelitian ini dilakukan dengan menggunakan bantuan SPSS 23, dengan meregresikan persamaan

$\mathrm{MN}=\alpha+\beta \mathrm{NS}+\beta \mathrm{KA}+\beta \mathrm{NS} * \mathrm{KEM}+\varepsilon$

Adapun hasil yang didapatkan adalah:

Tabel 12. Uji Regresi Moderasi

\begin{tabular}{|c|c|c|}
\hline Model & $\mathbf{t}$ & Sig \\
\hline NS & 1,292 & 0,203 \\
\hline KEM & $-0,830$ & 0,411 \\
\hline NS_KEM & 0,858 & 0,395 \\
\hline
\end{tabular}

Berdasarkan hasil uji regresi moderasi tersebut dapat diketahui bahwasannya variabel kemampuan akuntansi tidak mampu untuk memoderasi hubungan antara norma subjektif. Hal ini dikarenakan nilai NS_KM sebesar 0,395 lebih besar dari tingkat signifikansinya yakni 0,05 .

\section{Pembahasan Hasil Penelitian}

Hipotesis awal dalam penelitian ini menyatakan bahwa kemampuan akuntansi harusnya mampu untuk memoderasi hubungan antara variabel norma subjektif dengan variabel minat untuk membuat laporan keuangan berbasis SAK ETAP. Ketika seseorang telah memiliki dorongan atau motivasi dari pihak eksternal untuk membuat pelaporan keuangan, maka keinginan ini akan semakin kuat dan lebih mungkin untuk terlaksana apabila didukung oleh kemampuan individu tersebut dalam konteks ilmu akuntansi, hal ini juga berlaku sebaliknya. Namun, hasil penelitian ini menyatakan bahwa kemampuan akuntansi tidak mampu memoderasi hubungan antara norma subjektif dan minat untuk membuat pelaporan keuangan. Artinya hipotesis dalam penelitian ini ditolak. Temuan ini mengindikasikan bahwasannya kemampuan akuntansi bukanlah faktor pendukung yang dapat membuat seseorang menjadi 
"lebih" berminat untuk membuat laporan keuangan berbasis SAK ETAP khususnya bagi pengusaha UMKM yang ada di Kota Palembang. Laporan keuangan berbasis SAK ETAP masih dirasakan berat oleh para pengusaha UMKM di Kota Palembang, apalagi dengan kemampuan akuntansi yang memadai membuat para pengusaha tidak pernah melakukannya. Sehingga dapat dinyatakan bahwa masih rendahnya minat pengusaha UMKM khususnya usaha kecil yang ada di Kota Palembang dalam membuat pelaporan keuangan berbasis SAK ETAP.

Hal ini disebabkan rata-rata pengusaha UMKM di Kota Palembang belum memiliki kesadaran akan pentingnya pelaporan keuangan itu sendiri. Para pengusaha UMKM hanya menganggap membuat laporan keuangan merupakan aktivitas yang sia-sia karena tidak dapat menambah laba usaha dan mengeluarkan biaya yang besar karena harus merekrut pegawai yang khusus memiliki kemampuan akuntansi. Padahal dengan membuat laporan keuangan berbasis SAK ETAP, akan membuka akses bagi para pelaku usaha ini untuk dapat mengembangkan usahanya dengan memanfaatkan berbagai program penyaluran kredit khususnya kredit UMKM.

Hasil penelitian ini berbeda pada penelitian Nahar dan Widiastuti (2011) menunjukkan bahwa pengetahuan akuntansi berpengaruh positif terhadap penggunaan informasi akuntansi dalam membuat laporan keuangan berbasis SAK ETAP dan Sariningtyas dan Diah (2011) menyebutkan bahwa Hanum (2013) menyatakan variabel pengetahuan akuntansi, dan pengalaman dalam informasi akuntansi berpengaruh positif terhadap persepsi pengusaha kecil dan menengah pencatatan akuntansi. Dengan kata lain, ada faktor pendukung lain yang dapat lebih memperkuat atau memperlemah minat pelaku usaha kecil untuk membuat pelaporan keuangan. Seperti halnya kesadaran akan pentingnya pelaporan keuangan. Hal inilah yang menjadi implikasi utama dalam penelitian ini. Pihak eksternal yang berkepentingan seperti halnya Ikatan Akuntan Indonesia (IAI), Pemerintahan, Perbankan, dan pihak pemangku kepentingan lainnya sebaiknya lebih mendorong kesadaran para pelaku usaha khususnya usaha kecil yang ada di Indonesia. Selain mendorong kesadaran akan pentingnya akuntansi, pihak eksternal juga tetap harus memperhatikan kemampuan akuntansinya sehingga para pengusaha UMKM dapat menyambur era perdagangan bebas.

\section{KESIMPULAN DAN SARAN Kesimpulan}

Berdasarkan penelitian dan hasil pengujian MRA, maka dapat disimpulkan bahwa kemampuan akuntansi belum mampu untuk memoderasi hubungan antara variabel norma subjektif dengan variabel minat pengusaha UMKM untuk membuat pelaporan keuangan berbasis SAK ETAP. Hal ini menunjukkan bahwa kemampuan akuntansi bukanlah faktor pendukung yang dapat memperkuat ataupun memperlemah minat untuk membuat pelaporan keuangan. Dengan kata lain pengusaha UMKM yang ada di Kota Palembang memiliki pertimbangan pendukung lain dalam membetuk minatnya untuk membuat laporan keuangan berbasis SAK ETAP, sehingga para pengusaha memiliki standar international dalam pelaporan keuangan dan para pengusaha UMKM juga mampu bersaing di era perdagangan bebas.

\section{Saran}

Saran untuk peneliti selanjutnya menggunakan variabel moderasi lain seperti halnya kesadaran pentingnya akuntansi, hal ini mengingat bahwasannya walaupun seseorang memiliki dorongan dan kemampuan akuntansi yang baik, bukan berarti mereka akan mau membuat pelaporan keuangan. Artinya kesadaran akan pentingnya akuntansi dapat didiuga menjadi salah satu pemicu pendukung minat para pelaku usaha kecil di Kota Palembang untuk membuat pelaporan keuangan.

\section{DAFTAR PUSTAKA}

Ajzen, I., \& Fishbein, M. (1975)Belief, Attitude, Intention, and Behavior: An Introduction to Theory and Research, 129-385. Addison-Wesley, Reading, MA.

Ajzen, I. (1991). The Theory of Planned Behavior, Organizational Behavior andHuman Decision Processes. 50, 179-211.

Ajzen, I. (2005).Attitudes, Personality and Behavior. 2nd Edition, McGraw-Hill Professional Publishing, Berkshire, GBR. 
Andhika dan DamayantI. (2017). Niat Melakukan Pencatatan Akuntansi Pada Usaha Kecil Menengah: Pengetahuan Akuntansi Ataukah Herding?. Jurnal Ekonomi dan Bisnis. Volume 20 No. 2, Oktober 2017. ISSN $1979-6471$.

Andriani, L., A. T. Atmadja, dan N. K. Sinarwati. (2014). Analisis Penerapan Pencatatan Keuangan Berbasis SAK ETAP Pada Usaha Mikro Kecil Menengah (MKM) (Sebuah Studi Interpretif Pada Peggy Salon). E-Journal. Vol. 2. No. 1. p.1-12.

Hanum, Z. (2013). Pengaruh persepsi pengusaha kecil atas informasi akuntansi keuangan terhadap keberhasilan usaha. Jurnal Riset akuntansi dan Bisnis 2: 1-35.

Imam Ghozali. (2011). Aplikasi Analisis Multivariate dengan Program IBM SPSS. Badan Penerbit Universitas Diponegoro. Semarang.

Sariningtyas, P. dan Diah, T. (2011). Standar Akuntansi Keuangan Entitas Tanpa Akuntabilitas Publik Pada Usaha Kecil Dan Menengah. Jurnal Akuntansi dan Keuangan Indonesia. Vol. 1 No. 1.

Soraya dan Mahmud. (2016). Faktor- Faktor Yang Mempengaruhi Kebutuhan Standar Akuntansi Keuangan Entitas Tanpa Akuntabilitas Publik. Accounting Analysis Journal. Universitas Negeri Semarang. ISSN 2252-6765.

\section{Peraturan:}

Kabar bisnis. 2017

Undang - undang No. 20 Tahun 2008 tentang Usaha Mikro, Kecil dan Menengah (UMKM).

Kitab Undang-Undang Hukum Dagang (KUHD) pasal 6. 